\title{
Removal of Chloroform from Aqueous Solution by the Adsorption onto Zero Valent Iron Supported on Zeolite as an Efficient Adsorbent
}

\author{
Atyaf Khalid Hameed ${ }^{1 *}$, Mohd Hasbi Ab. Rahim ${ }^{1}$, Nugroho Dewayanto ${ }^{2}$ and Mohd Ridzuan Nordin ${ }^{3}$ \\ ${ }^{1}$ Faculty of Industrial Sciences and Technology, Universiti Malaysia Pahang, Lebuhraya Tun Razak 26300 Kuantan, Pahang, Malaysia \\ ${ }^{2}$ Malaysian Institute of Chemical and Bioengineering Technology, Universiti Kuala Lumpur, Vendor City 1988, 78000 Alor Gajah, Melaka, \\ Malaysia \\ ${ }^{3}$ Faculty of Technology Management and Technopreneurship, Universiti Teknikal Malaysia Melaka, Hang Tuah Jaya, 76100 Durian Tunggal, \\ Melaka, Malaysia
}

*Corresponding author: Atyaf Khalid Hameed, Faculty of Industrial Sciences and Technology, Universiti Malaysia Pahang, Lebuhraya Tun Razak 26300 Kuantan, Pahang, Malaysia, E-mail: atyaf.ump2015@gmail.com

Received date: Oct 05, 2018; Accepted date: Oct 22, 2018; Published date: Oct 29, 2018

Citation: Hameed AK, Ab. Rahim MH, Dewayanto N, Nordin MR (2018) Removal of Chloroform From Aqueous Solution by the Adsorption onto Zero Valent Iron Supported on Zeolite as an Efficient Adsorbent. Int J Appl Sci Res Rev. Vol.5 No.3:14.

Copyright: (C) Hameed AK, et al. This is an open-access article distributed under the terms of the Creative Commons Attribution License, which permits unrestricted use, distribution, and reproduction in any medium, provided the original author and source are credited.

\section{Abstract}

Chloroform is one of the Volatile Organic Compounds (VOCs). Chloroform is the most commonly exist compound of the tri-halo methane (THM); THMs are Halogen-substituted single-carbon compounds with the general formula $\mathrm{CHX}_{3}$. The adsorption of chloroform $\left(\mathrm{CHCl}_{3}\right)$ from aqueous solution was investigated in series of batch experiment. Two type of adsorbents of zero valent iron were prepared as NZVI and NZVI/ZSM via the reduction method by using sodium boro- hydride as reducing agent. The prepared adsorbent were characterized by the field emission scanning electron microscopy (FESEM), Fourier transform infrared spectroscopy (FTIR), Brunner -Emmett -Teller (BET), and $X$-ray powder diffraction (XRD). The BET surface areas of the adsorbents were 254.33, 41, and $116.52 \mathrm{~m}^{2} / \mathrm{g}$ for ZSM, NZVI, and NZVI/ZSM, respectively. The adsorption isotherm studies were conducted at various initial concentrations of $\mathrm{CHCl}_{3}(10-40) \mathrm{mg} / \mathrm{L}$. Langmuir and Freundlich adsorption isotherm models were employed to fit the adsorption characteristic of the adsorbent. The removal efficiency of $\mathrm{CHCl}_{3}$ via the $\mathrm{NZVI} / \mathrm{ZSM}$ from aqueous solution was found to be $19.92 \mathrm{mg} / \mathrm{g}$, which conducted from the Langmuir slope. In addition the adsorption reached equilibrium within $90 \mathrm{~min}$ at optimum $\mathrm{pH}$ value of 9. It was found that Freundlich isotherm characterized the adsorption process better than that of Langmuir for NZVI/ZSM as indicated by higher correlation coefficient value. Hence, the adsorption of $\mathrm{CHCl}_{3}$ onto $\mathrm{NZVI/ZSM} \mathrm{can} \mathrm{consider} \mathrm{as} \mathrm{a} \mathrm{multilayer} \mathrm{adsorption} \mathrm{rather}$ than a monolayer adsorption and the prepared adsorbents were found to be effect in the removal of $\mathrm{CHCl}_{3}$ from aqueous solution.
Keywords: Water treatment; Precipitation; As(V); Arsenic removal; Sorption; Manganese

\section{Introduction}

It is well known that trace amounts of chloroform are contained in tap water and ground water. Production of chloroform in tap water is caused by reaction between residual chlorine and organic compounds [1]. Also, chloroform has been used in a wide range of industrial processes and to produce industrial products, for example, lubricants, cleaning solvents, paper bleaching, intermediates for pharmaceuticals, herbicides and fungicides [2]. Unfortunately, emissions of this compound are harmful to the environment, and in particular it is an important contributor to the destruction of the ozone layer [3]. Also it is toxic or carcinogenic and thus represents a direct health risk such as liver and kidney cancer, nervous system and reproductive effects [4-6]. Several treatment methods have been proposed for the removal of hydrocarbons especially the Low molecular weight hydrocarbons as chloroform.

Previously, the treatment of hydrocarbons on activated carbon, oxidation [7], coagulation- flocculation [8] Ion chromatography [9], Nano Chromatography and Capillary Electrophoresis [10], stripping [11] and biological treatment [12] were investigated. The removal can be performed with adsorption method using different adsorbents with high adsorption efficiency such as Nano adsorbents [13-23]. Zeolite is a type of crystalline material, containing silicon, aluminum and oxygen atoms. Zeolite can be used as catalyst as well as adsorbent material because of its high surface area and high chemical stability. By reducing the particle size, the diffusion path length decreases and hence active sites are readily accessible $[22,23]$. In chemistry, ZSM-5 is used to separate 
molecules [24]. Its well- defined pore structure and adjustable acidity make them attractive in numerous reactions [25].

Utilization of zero-valent iron (e.g. NZVI) in the remediation application was started in the last decade [26-41]. Previously the researchers presented rapid de-halogenation of Carbon Tetrachloride (CT) and chloroform using iron particles. The aim of this study was the preparation and the characterization of the new modified adsorbents as (NZVI/ZSM) in the removal of chloroform from aqueous solution by the adsorption technique. The analysis of equilibrium data (adsorption) by model fittings is an important step to evaluate the suitable model for describing the adsorption process and the effected parameters such as contact time, initial concentration, temperature and the $\mathrm{pH}$ effect. Two isotherm models as Langmuir and Freuindlch were used to describe the equilibrium adsorption data for chloroform adsorption. On the other hand, the kinetic data was analyzed via the pseudo-fistorder and pseud-second - order models.

\section{Materials and Methodology}

\section{Materials}

Chloroform $\left(\mathrm{CHCl}_{3}\right)$ was obtained from sigma Aldrich, Sodium borohydride $\left(\mathrm{NaBH}_{4}\right)$ of purity $98.5 \%$ and iron (III) chloride hex hydrate $\left(\mathrm{FeCl}_{3} \cdot 6 \mathrm{H}_{2} \mathrm{O}\right)$ of purity $99.0 \%$ are obtained from Merck. Zeolite (ZSM-5) is purchased from Merck and the ZSM-5 with ratio of silica/Alumina ( $\mathrm{Si} / \mathrm{Al}=30$ ) is supplied by Zeolyst International. Sodium hydroxide $(\mathrm{NaOH})$ and hydrochloric acid $(\mathrm{HCl})$ are obtained from Sigma-Aldrich, while analytical grade absolute ethanol and acetone are obtained from Merck and used directly without purification.

\section{Adsorbent preparation and characterization}

The ZSM-5, the commercial sample is subjected to a calcination treatment performed at $300^{\circ} \mathrm{C}$ for $1 \mathrm{~h}$ under static air environment [41], then, the impregnation of nano zero valent iron was carried out by the redaction method as sodium boro hydride reducing agent. On the other hand, the characterization of the prepared adsorbents were determined via the Fourier Transform Infra-Red (FTIR), N2- Physisorption was used to evaluate the porosity and the surface area and the Bruner-Emmett-Teller (BET) equation was employed to calculate the specific surface area. The X-ray diffraction (XRD) and the Field Emission Scanning Electron Microscopy (FESEM).

\section{The adsorption studies and the related \\ parameters}

The adsorptions of the Chloroform $\left(\mathrm{CHCl}_{3}\right)$ onto the adsorbents are conducted in batch mode. The required amount of adsorbent is added into the $\left(\mathrm{CHCl}_{3}\right)$ solution (of certain concentration) in the $250 \mathrm{~mL}$ conical flasks. The flasks are placed on the orbital shaker operating at $150 \mathrm{rpm}$ in room temperature $(27 \pm 2 \circ \mathrm{C})$. The initial and final concentrations of $\mathrm{CHCl}_{3}$ are determined by using UV spectrometer (Genesys 10S
UV-VIS spectrophotometer). Detailed analysis by using UV spectrometer.

\section{Contact time}

Equilibrium time of adsorption was determined by using 0.1 $\mathrm{g}$ of adsorbent in $100 \mathrm{~mL}$ of $20 \mathrm{mg} / \mathrm{L}$ of the Chloroform $\left(\mathrm{CHCl}_{3}\right)$ solutions. The mixture was equilibrated by shaking thoroughly at $150 \mathrm{rpm}$ in orbital shaker. Samples are taken out at different time intervals viz. 2, 4, 8, 15, 30, 60, 90, 120 and $180 \mathrm{~min}$ at $\mathrm{pH}$ value of 7 , in room temperature $\left(27 \pm 2^{\circ} \mathrm{C}\right)$. At the end of the shaking period, the solution was sampled by a syringe. The samples were then centrifuged and the supplements are kept for further analysis. The equilibrium time was an important factor to set the adsorption time for each adsorbent.

\section{Initial concentration}

The effect of initial concentration of the $\left(\mathrm{CHCl}_{3}\right)$ on the adsorption performance is carried out through as a series of adsorption experiments with different initial concentrations ranging from 10 to $40 \mathrm{mg} / \mathrm{L}$. The experiments are performed by using $100 \mathrm{~mL}$ from the $\left(\mathrm{CHCl}_{3}\right)$ solution. The adsorbent dosage is $0.1 \mathrm{~g} / \mathrm{L}$. The samples used to determine the adsorption performance are available after the batch mixture is stirred for a suitable equilibrium time (60 or $90 \mathrm{~min}$ ).

\section{Temperature}

To study the temperature effect, the experiment is operating and the experimental were carried out in temperature range from $30-50 \circ \mathrm{C}$.

\section{$\mathrm{pH}$}

Different $\mathrm{pH}$ values are considered: 2, 4, 7 and 9. The $\mathrm{pH}$ of the solution is measured by the $\mathrm{pH}$ meter. The $\mathrm{pH}$-meter is calibrated by using a $\mathrm{pH}$ buffer of $4.0,7.0$, and 10 to ensure the accuracy of the $\mathrm{pH}$ measurement. The initial $\mathrm{pH}$ of the solution is adjusted by using $1 \mathrm{M} \mathrm{HCl}$ or $1 \mathrm{M} \mathrm{NaOH}$. Then, the adsorption performance is performed.

\section{Adsorption isotherm}

The isotherm studies are conducted by series of batch adsorptions. The initial pollutant concentration is ranging from 10 to $40 \mathrm{mg} / \mathrm{L}$. Two models that are commonly used to simulate the adsorption isotherms are Langmuir and Freundlich isotherms models. The well-known expression of the Langmuir model is given in Equation 1.1:

$$
q_{e}=\frac{K_{L} q_{\max } C_{e}}{1+K_{L} C_{e}}
$$

Where qe is the equilibrium pollutant concentration on the adsorbent (mg/g), $\mathrm{Ce}$ is the equilibrium pollutant concentration in the solution $(\mathrm{mg} / \mathrm{L})$, qmax is the monolayer capacity of the adsorbent $(\mathrm{mg} / \mathrm{g}$ ) and $\mathrm{KL}$ is the Langmuir adsorption constant $(\mathrm{L} / \mathrm{mg})$ which is related to the adsorption energy. On the other hand, the Freundlich Equation can be written as Equation 1.2: 


$$
q_{e}=K_{F} C_{e}^{1 / n}
$$

Where $\mathrm{q}_{\mathrm{e}}$ is the equilibrium pollutant concentration on adsorbent (mg/g), Ce is the equilibrium pollutants concentration in solution (mg/L) and KF (mg/L) $1 / \mathrm{n} / \mathrm{g} / \mathrm{mg}$ ) $1 / n$ and $n$ are the Freundlich constants characteristic of the system, indicators of adsorption capacity and adsorption intensity, respectively.

\section{Kinetic studies of $\mathrm{CHCl}_{3}$ adsorption}

The kinetic studies are conducted by series of batch adsorptions running at initial pollutant concentration of 20 $\mathrm{mg} / \mathrm{L}$. The procedures of kinetic adsorption tests are identical to those of batch equilibration tests. However, the aqueous samples are taken at various time intervals. The first order rate expression based on adsorbent capacity is generally expressed as in Equation 1.3:

$$
\frac{d q}{d t}=k_{1}\left(q_{e}-q\right)
$$

Integration of Equation 3.5 with the boundary conditions: $\mathrm{t}=0, \mathrm{q}=0$, and at $\mathrm{t}=\mathrm{t}, \mathrm{q}=\mathrm{q}$, gives Equation 1.4:

$$
L_{n}\left(q_{e}-q\right)=L n q_{e}-k_{1} t
$$

Pseudo second order model is derived on the basis of the sorption capacity of the adsorbent phase, expressed as in Equation 1.5:

$$
\frac{d q}{d t}=k_{2}(q e-q)^{2}
$$

Integration of Equation 3.8 with the boundary conditions $t=$ $0, \mathrm{q}=0$, and at $\mathrm{t}=\mathrm{t}, \mathrm{q}=$

q, resulted gives Equation 1.6:

$\frac{1}{q_{e}-q}=\frac{1}{q_{e}}+k_{2} t$

1.7:

The linear form of Equation 3.8 can be written as Equation

$$
\frac{t}{q}=\frac{t}{q_{e}}+\frac{1}{k_{2} q_{e}}
$$

\section{Result and Discussion}

\section{The adsorbent characterization The XRD analysis}

The XRD pattern of the ZSM-5 is illustrated in Figure 1a. The main peaks appear at $2 \theta$ of $7.92^{\circ}, 8.76^{\circ}, 15.84^{\circ}, 23.6^{\circ}, 37.48^{\circ}$, $45.39^{\circ}$ and $54.94^{\circ}$ in the detection of $\left(\begin{array}{lll}1 & 0 & 1\end{array}\right),\left(\begin{array}{lll}2 & 0 & 0\end{array}\right),\left(\begin{array}{lll}2 & 0 & 2\end{array}\right),(3$ $32),\left(\begin{array}{lll}2 & 8 & 0\end{array}\right),\left(\begin{array}{lll}0 & 8 & 4\end{array}\right)$ and (1 08 ), respectively, indicating the crystallization of ZSM-5. The XRD diffractions of NZVI/ZSM were illustrated in Figure 1b. The presence of Zero Valent Iron is indicated by a distinct peak at $2 \theta$ of $44.45^{\circ}$ with detection (1 11 ), which is related to $-\mathrm{Fe}$ (NZVI) as observed in the diffractogram of NZVI/ZSM. It appears that the ZeroValent Iron is successfully loaded into the supports.

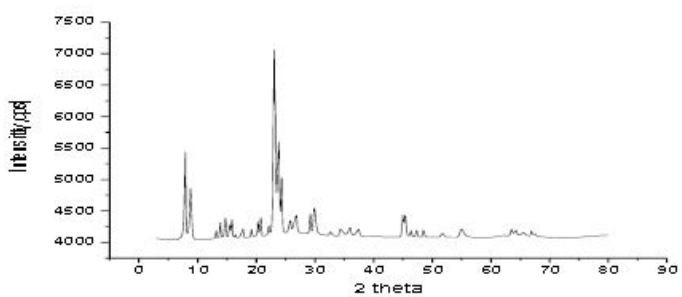

(a)

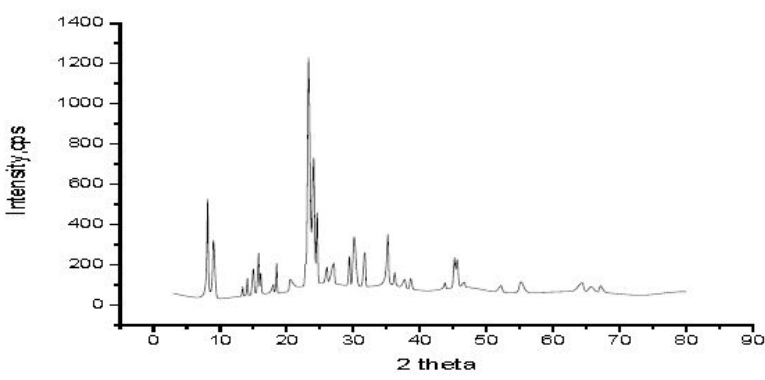

(b)

Figure 1: The XRD diffractogram of (a) ZSM, and (b) of NZVI/ ZSM.

\section{N2-Physisorption analysis of adsorbents nano zero valent iron (NZVI)}

Parameters such as BET surface area pore volume and pore size of adsorbents are summarized in Table 1.

Table 1: BET surface area (SBET), pore volume and pore size of the prepared adsorbents.

\begin{tabular}{|l|l|l|l|}
\hline Adsorbent & BET m2/g & $\begin{array}{l}\text { BJH } \\
\text { adsorption } \\
\text { Pore volume } \\
\text { cm3/g }\end{array}$ & $\begin{array}{l}\text { BJH } \\
\text { adsorption } \\
\text { Pore size } \AA\end{array}$ \\
\hline $\mathrm{NZVI}$ & 40.65 & 0.165 & 152.70 \\
\hline $\mathrm{ZSM}$ & 254.33 & 0.095 & 63.28 \\
\hline $\mathrm{NZVI/ZSM}$ & 116.52 & 0.055 & 91.22 \\
\hline
\end{tabular}

The surface areas of NZVI are found to be $40.65 \mathrm{~m}^{2} / \mathrm{g}$ Meanwhile, their pore sizes is $152.70 \AA$. It is clear that the surface area and the pore size of NZVI obtained by this study is larger than that reported previously [42], which may be attributed to different experimental conditions. Therefore, the surface area of the adsorbent is dependent on the particle 
size, morphology, surface texturing and porosity of the prepared adsorbent. On the other hand, the N2 adsorptiondesorption isotherms for unsupported adsorbents (type I isotherm) depend on (IUPAC) classification at 77K illustrated in Figure 2.

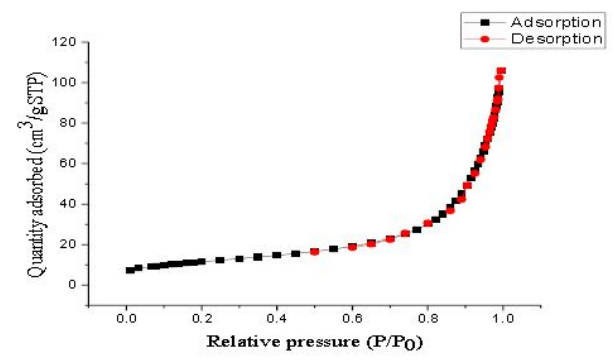

Figure 2: N2 adsorption/desorption equilibrium isotherms at $77 \mathrm{~K}$ for NZVI.

\section{FTIR Analysis}

\section{Nano zero valent iron (nzvi)}

Figure 3 shows broad peaks at around $3200-3600 \mathrm{~cm}^{-1}$ in both spectra. These peaks are related to the $\mathrm{OH}$ vibration stretching band as presented in Figure 3 clearly. These - $\mathrm{OH}$ groups may come from the moisture water. The peak at a wavenumber of $1653 \mathrm{~cm}^{-1}$ observed may correspond to the bending modes of $\mathrm{OH}$ group [43]. As shown in peak at 1427 $\mathrm{cm}^{-1}$ is related to the Fe-O stretching vibration, peak at 1328 $\mathrm{cm}^{-1}$ is related to the $\mathrm{Fe}-\mathrm{O}$ bending out of the structure and peak at $710 \mathrm{~cm}^{-1}$ is related to is attributed to the NZVI (Fe0) as reported by the previous studies $[44,45]$.

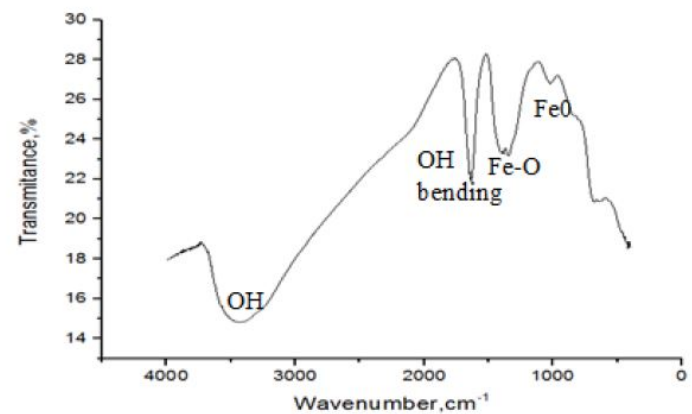

Figure 3: FTIR spectrum of NZVI.

The FTIR spectra of NZVI/ZSM are shown in Figure 4 . The broad spectrum of adsorption bands at wavenumbers of 3800 $\mathrm{cm}^{-1}$ and $3400 \mathrm{~cm}^{-1}$ are related to the intermolecular $\mathrm{OH}$ (Si$\mathrm{OH}-\mathrm{Si}$ and $\mathrm{Al}-\mathrm{OH}-\mathrm{cm}^{-1}$ [46]. Also, they are related to $\mathrm{H}-\mathrm{O}-\mathrm{H}$ stretching. The band at wavenumbers of $1648 \mathrm{~cm}^{-1}$ and 1661 $\mathrm{cm}^{-1}$ can be attributed to $\mathrm{O}-\mathrm{H}$ bending [47].

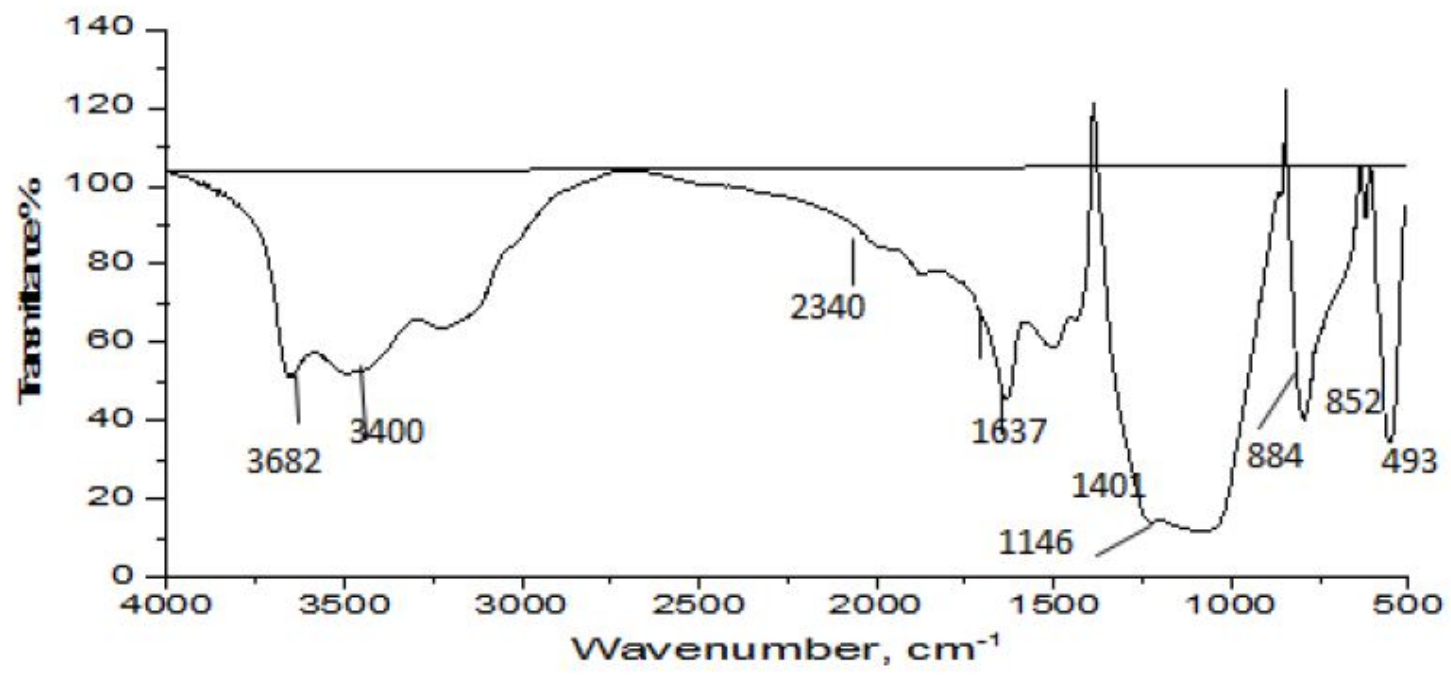

Figure 4: FTIR spectrum of ZSM-5.

\section{FESEM-EDX for ZSM and NZVI/ZSM}

The SEM micrograph for ZSM-5 is illustrated in Figure $\mathbf{5}$ showing the surface morphology of ZSM-5. Irregular crystallite particles are observed, similar to those reported by others $[48,49]$. 


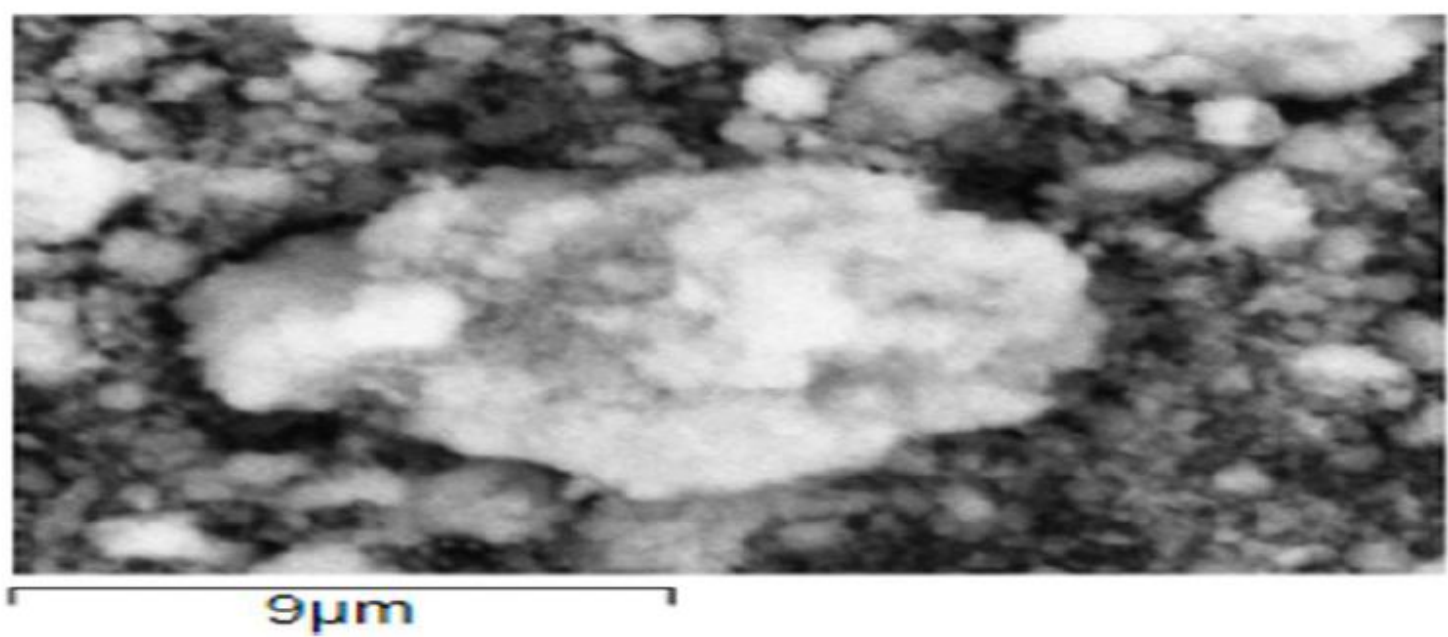

Figure 5: SEM micrograph for ZSM-5.

The EDX spectra, Figure 6 for ZSM- 5 appears that the peak of the value $1.8 \mathrm{KeV}$ was related to the $\mathrm{Si}$, while peak in the value of $1.6 \mathrm{KeV}$ was related to $\mathrm{Al}$ and peak in the value of 0.6 $\mathrm{KeV}$, was related to the $\mathrm{O}$ atom.

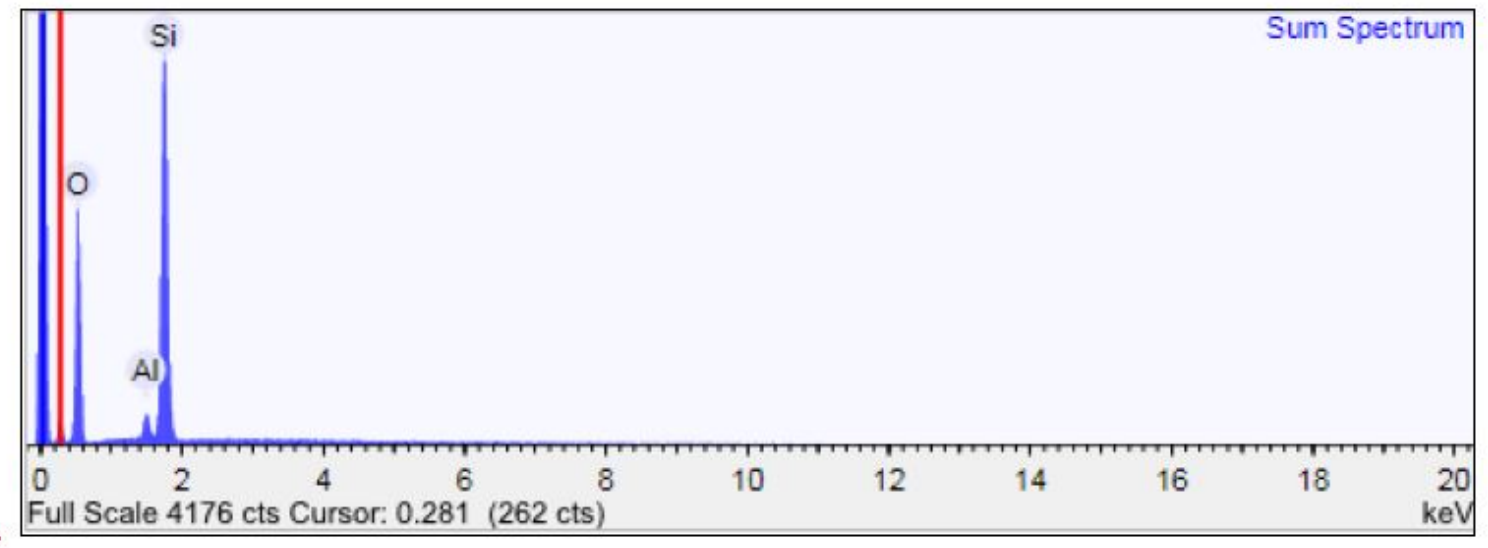

Figure 6: The EDX spectra of ZSM-5

Table 2: The EDX analysis of ZSM, and NZVI/ZSM.

\begin{tabular}{|c|c|c|c|}
\hline Adsorbents & Element\% & Weight $\%$ & Atomic weight $\%$ \\
\hline \multirow[t]{3}{*}{ ZSM-5 } & $\mathrm{O}$ & 60.86 & 73.15 \\
\hline & $\mathrm{Si}$ & 37.21 & 25.47 \\
\hline & $\mathrm{Al}$ & 1.93 & 1.38 \\
\hline \multirow[t]{4}{*}{ NZVI/ZSM } & 0 & 75.63 & 85.69 \\
\hline & $\mathrm{Si}$ & 18.55 & 11.97 \\
\hline & $\mathrm{Al}$ & 1.29 & 0.87 \\
\hline & $\mathrm{Fe}$ & 4.53 & 1.47 \\
\hline
\end{tabular}

The EDX analysis as shown in Table 2 appears the weight and the atomic weight for the elements in ZSM- 5 of the entity of silicon, aluminium and oxygen percentage. As appear in Table 2, the weight and the atomic weight for silicon, 
aluminum and oxygen percentage in the ZSM-5 surface. The percentage of $\mathrm{Si}$ atoms in the ZSM-5 at the atomic value of $25.47 \%$ with the weight value of $37.20 \%$, the $O$ atoms in the ZSM-5 at the atomic value of $73.15 \%$ with the weight value of $60.86 \%$ and the $\mathrm{Al}$ atoms in the ZSM-5 at the atomic value of $1.37 \%$ with the weight value of $1.93 \%$, respectively.

The mapping distributions (from EDX analysis) for oxygen, aluminium, silicon and mixture of the three elements on the surface of ZSM-5 are presented in Figure 7a-d respectively. It is obvious that the oxygen distribution on the surface is homogeneous as shown in Figure 7a. But, the amount of aluminium (see Figure $\mathbf{7 b}$ seems to be less in the structure of ZSM-5 as compared to that of $\mathrm{Si}$ as shown in Figure 7c. On other the hand, Figure $\mathbf{7 d}$ shows the distribution for the three elements on the surface of ZSM-5.
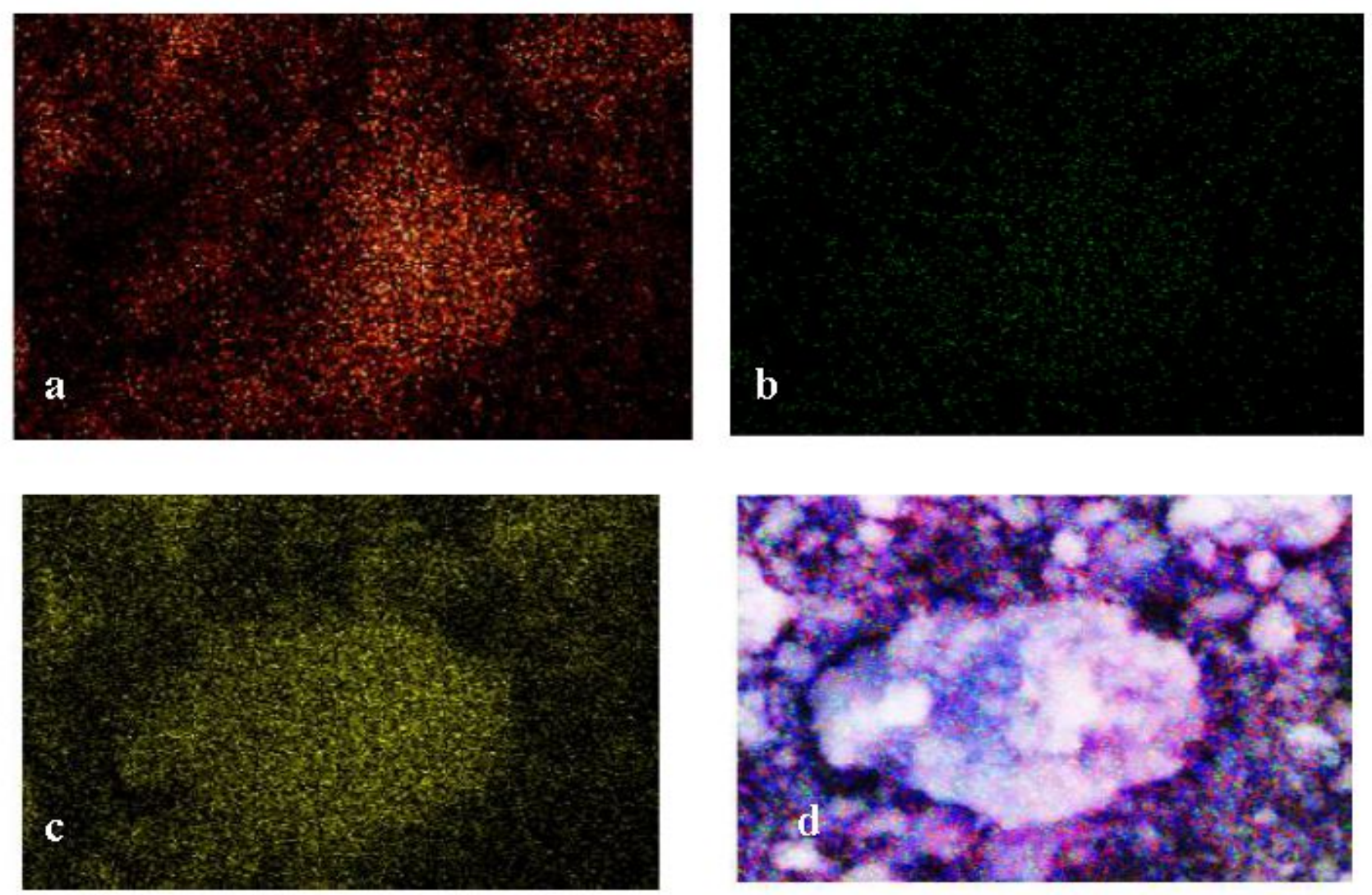

Figure 7: EDX mapping distribution for (a) oxygen, (b) aluminum, (c) silicon and (d) mixture for three elements for ZSM-5 surface.

\section{Adsorption study}

The adsorption properties of NZVI/ZSM was evaluated in sorption of $\mathrm{CHCl}_{3}$ on the other hand, $\mathrm{CHCl}_{3}$ consider as low solubility in water, $\mathrm{Cs}$ of Chloroform is $68.67 \mathrm{mmole} / \mathrm{dm}^{3}$ of Chloroform Thus, $\mathrm{CHCl}_{3}$ stock solution prepared via the dissolving in in alcohol as 2- propanol instead of distilled water.

\section{Adsorption isotherm of $\mathrm{CHCl}_{3}$ onto nzvi/zsm}

Adsorption isotherm studies are performed by batch adsorption of $\mathrm{CHCl}_{3}$ at various initial concentrations ranging from $10-40 \mathrm{mg} / \mathrm{L}$. Triplicate the data collection to evaluate the vertical error bars and the average deviation on the data points. The Langmuir and Freundlich constants of adsorption of $\mathrm{CHCl}_{3}$ onto $\mathrm{NZVI} / \mathrm{ZSM}$ are $0.0368 \mathrm{~L} / \mathrm{mg}$ and $1.1123 \mathrm{~g} / \mathrm{L}$ respectively. The maximum adsorption capacities of $\mathrm{CHCl}_{3}$ onto $\mathrm{NZVI/ZSM}$ and determined by the Langmuir isotherm are $19.92 \mathrm{mg} / \mathrm{g}$. In general, Freundlich isotherm can better characterize the adsorption process for NZVI/ZSM. The surface heterogeneities of $\mathrm{NZVI} / \mathrm{ZSM}$ are prevalent because $1 / \mathrm{n}^{\sim 1.0}$ [50]. Hence, the adsorption of $\mathrm{CHCl}_{3}$ onto $\mathrm{NZVI/ZSM}$ can be considered as multilayer adsorption. The Langmuir and Freundlich isotherm models for adsorption of $\mathrm{CHCl}_{3}$ onto $\mathrm{NZVI} / \mathrm{ZSM}$ was presented in Figure $\mathbf{8 a}$ and $\mathbf{8 b}$ respectively. 


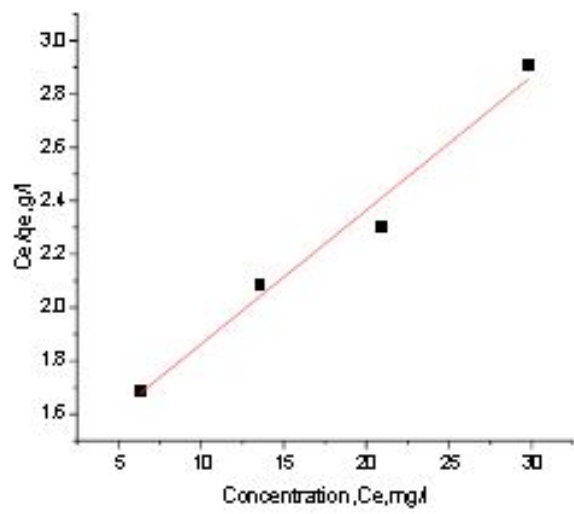

(a)

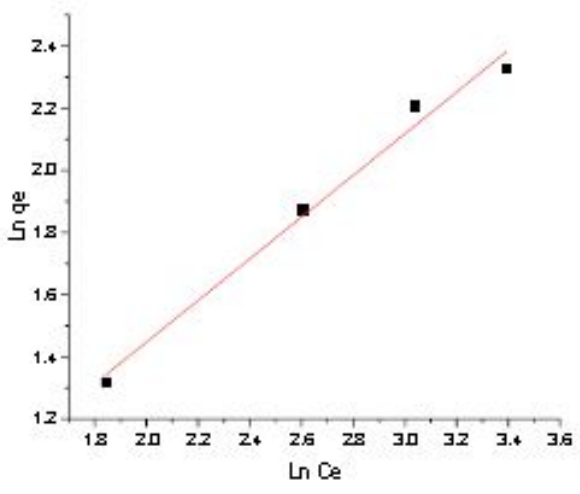

(b)

Figure 8: Langmuir (a) and Freundlich (b) adsorption isotherm model for sorption of $\mathrm{CHCl3}$ onto NZVI/ZSM.

The parameters corresponding to the fitting of these results to the Langmuir and Freundlich isotherm models are summarized in Table 3 . The maximum adsorption uptakes values of the prepared adsorbents are comparable with some other adsorbent as shown in the Table 3.

Table 3: Isotherm parameters of $\mathrm{CHCl}_{3}$ adsorption onto $\mathrm{NZVI} / \mathrm{ZSM}$ with comparsion by uptake value from the literatures.

\begin{tabular}{|c|c|c|c|c|c|c|c|}
\hline \multirow[t]{2}{*}{ Absorbents } & \multicolumn{3}{|l|}{ Langmuir } & \multicolumn{3}{|c|}{ Freundlich } & \multirow{3}{*}{$\begin{array}{l}\text { Reference } \\
\text { This study }\end{array}$} \\
\hline & $\mathrm{KL} \mathrm{L/mg}$ & qmax, mg/g & $\mathbf{R 2}$ & KF & $1 / N$ & R2 & \\
\hline NZVI/ZSM & 0.0368 & 19.92 & 0.9786 & 1.1123 & 0.67 & 0.9872 & \\
\hline Activated carbon SKD515 & 5.47 & 9.69 & 0.9960 & 12.15 & 0.78 & 0.9500 & {$[4]$} \\
\hline Nano- $\mathrm{TiO}_{2}$ & - & 57.6 & - & - & - & - & [3] \\
\hline $\begin{array}{l}\text { Rectorite/ } \\
\text { Chitosan, nanocomposite }\end{array}$ & 0.7 & 6.3 & - & 2.3 & 0.7 & - & [9] \\
\hline
\end{tabular}

\section{Kinetic studies of $\mathrm{CHCl}_{3}$ onto $\mathrm{NZVI} / \mathrm{ZSM}$}

This experiment was carried out at the variation of time of contact (0 to $180 \mathrm{~min}$ ). Generally, adsorption increases during the first hour and it decays thereafter. The kinetic experiments are similar to the batch equilibrium tests; however, the samples are taken at certain time instant within $180 \mathrm{~min}$. The kinetic studies are conducted by a series of batch adsorptions at initial $\mathrm{CHCl}_{3}$ concentration of $20 \mathrm{mg} / \mathrm{L}$. Linear plot of both first and second order kinetic models are illustrated in Figure 9a and $b$ while the kinetic parameters calculated were summarized in Table 4. Linear regression of both models provided the correlation coefficient value of 0.9439 for pseudo-first order and value of 0.9944 for pseudo second order for NZVI/ZSM. In Table 4 the qe experimental data of pseudo-second order near to the calculate value of the $\mathrm{q}_{\mathrm{e}} \mathrm{Cal}$ by the slope of this model. As result, the pseudo second order model is more suitable to be applied in this study (higher R2).

Table 4: Kinetic parameters of the adsorption of $\mathrm{CHCl} 3$ onto $\mathrm{NZVI} / \mathrm{ZSM}$ were collected in this study

\begin{tabular}{|c|c|c|c|c|c|c|c|}
\hline Adsorbent & $\mathbf{k}^{1}, \min -1$ & $\mathrm{q}_{\mathrm{e}}, \mathrm{Cal} \mathbf{m g} / \mathrm{g}$ & R2 & $\mathbf{k}^{2}, \mathbf{g} / \mathrm{mg} \min$ & $\begin{array}{l}q_{\mathrm{e}}, \\
\mathrm{mg} / \mathrm{g}\end{array}$ & $\mathbf{R}^{2}$ & $q_{e} m g / g$ \\
\hline NZVI/ZSM & 0.030 & 7.75 & 0.9439 & 0.11 & 12.53 & 0.9944 & 12.08 \\
\hline
\end{tabular}




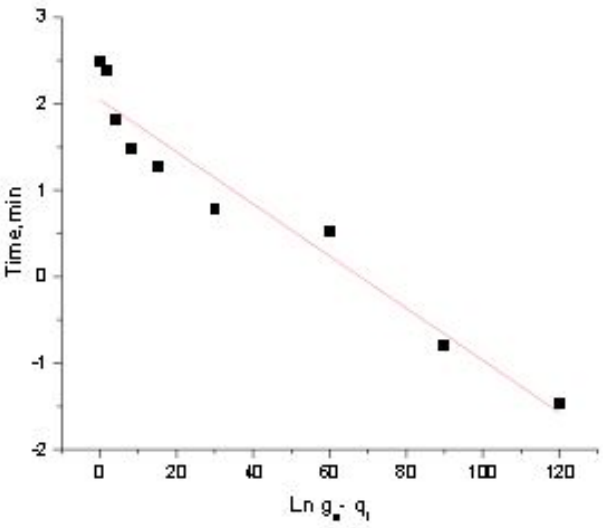

(a)

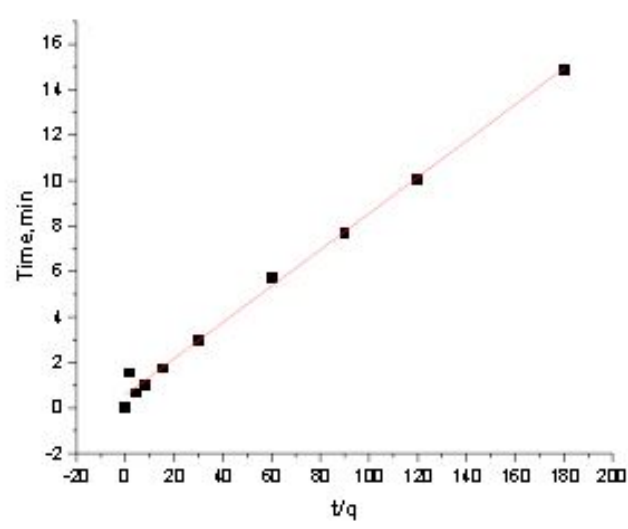

(b)

Figure 9: Liner plot of pseudo-first-order (a) and pseudo-second-order (b) kinetic models for adsorption of $\mathrm{CHCl}_{3}$ onto $\mathrm{NZVI/}$ ZSM.

\section{Effect of temperature}

The effects of temperature on the adsorption equilibrium of $\mathrm{CHCl}_{3}$ onto $\mathrm{NZVI} / \mathrm{ZSM}$ was presented in Figure 10. Generally, the adsorption of $\mathrm{CHCl}_{3}$ increases as the temperature increases from $30^{\circ} \mathrm{C}$ to $50^{\circ} \mathrm{C}$. As result, the uptake of $\mathrm{NZVI} / \mathrm{ZSM}$ with a value of $15.499 \mathrm{mg} / \mathrm{g}$ and removal of $78.56 \%$ at $50^{\circ} \mathrm{C}$.

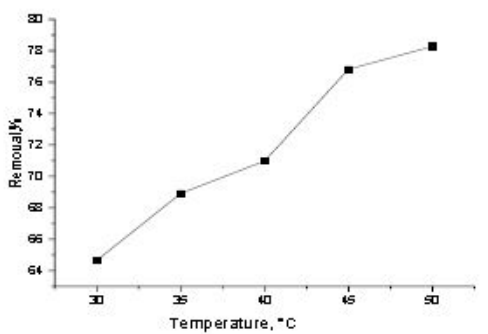

Figure 10: Effect of adsorption temperature on $\mathrm{CHCl}_{3}$ adsorption onto $\mathrm{NZVI/ZSM}$ removal.

\section{Effect of $\mathrm{pH}$ of $\mathrm{CHCl}_{3}$ adsorption on to $\mathrm{NZVI} / Z \mathrm{SM}$}

Affected factor on the adsorption of $\mathrm{CHCl}_{3}$ is the $\mathrm{pH}$ of the solution. It is generally expected that adsorption increases as $\mathrm{pH}$ increases. As shown in Figure 4, the removal of $\mathrm{CHCl}_{3}$ increases significantly as $\mathrm{pH}$ increases from 2 to 9 . In this study, the removal rate of $\mathrm{CHCl}_{3}$ is the highest as $\mathrm{pH}=9$. Initial $\mathrm{pH}$ of the solution was adjusted by using $1 \mathrm{M} \mathrm{HCl}$ or $1 \mathrm{M} \mathrm{NaOH}$.

The effects of the $\mathrm{pH}$ solution of the adsorptions of $\mathrm{CHCl}_{3}$ onto $\mathrm{NZVI/ZSM}$ is shown in Figure 11. Here, the removal of $\mathrm{CHCl}_{3}$ increases significantly as $\mathrm{pH}$ increases from 2 to 9 . In this study, the highest $\mathrm{CHCl}_{3}$ removal is attained when $\mathrm{pH}=9$ with
$\mathrm{CHCl}_{3}$ removal as high of $50.37 \%$ for $\mathrm{NZVI} / \mathrm{ZSM}$ at $\mathrm{CHCl}_{3}$ initial concentration of $20 \mathrm{mg} / \mathrm{L}$.

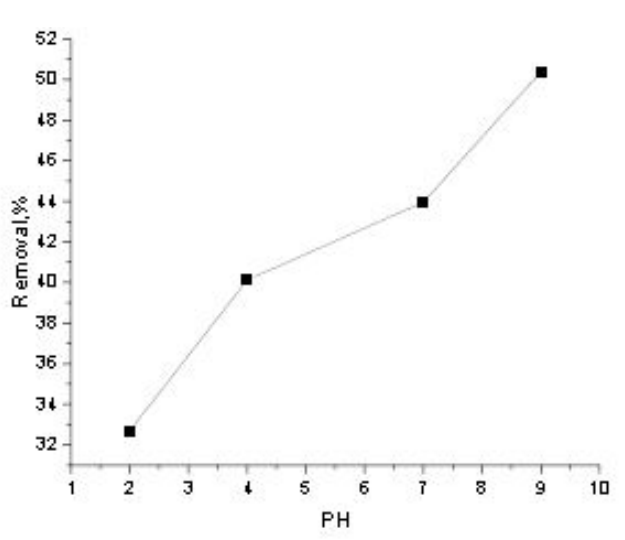

Figure 11: Effect of adsorption $\mathrm{pH}$ onto $\mathrm{CHCl}_{3}$ adsorption onto $\mathrm{NZVI} / \mathrm{ZSM}$ removal.

\section{Conclusion}

In this study, the preparation and characterization of $\mathrm{NZVI/ZSM}$ was determined via the adsorption studies in batch mode. The evaluation of the adsorption performance of the prepared adsorbents were proven via the isotherm studies by Langmuir and Freundlich models, Freundlich isotherm can better characterize the adsorption process of $\mathrm{CHCl}_{3}$ onto $\mathrm{NZVI} /$ ZSM. Hence, the adsorption of $\mathrm{CHCl}_{3}$ onto $\mathrm{NZVI} / \mathrm{ZSM}$ can be considered as multilayer adsorption. On the other hand, the kinetic studies by pseudo first and second order model were carried out for the adsorption of $\mathrm{CHCl}_{3}$ onto $\mathrm{NZVI} / \mathrm{ZSM}$. The pseudo first order and the pseudo second order kinetic models are examined. It seems that the pseudo second order kinetic model fits well with the experimental data. The effect of the 
adsorption efficiency of NZVI/ZSM was increased with increased temperature and $\mathrm{pH}$ to 9 . From the all above, the ZSM- 5 as supporting materials is perfect in stabilizing the NZVI; increase theadsorption efficiency at value of $19.92 \mathrm{mg} / \mathrm{g}$ and this adsorbent is comparable with other adsorbents from the literature. These new adsorbents prevent the agglomeration of the Nano zero valent iron (NZVI) and could be employed as efficient applicable and suitable adsorbents for the removal of $\mathrm{CHCl}_{3}$ from aqueous solutions.

\section{Acknowledgment}

The financial support by UMP Postgraduate Research Grant no. GRS 140374 for this re-search is gratefully acknowledged.

\section{References}

1. Background document for development of WHO Guidelines for Drinking-water Quality, World Health Organization 2004.

2. Chen $\mathrm{ChH}$, Dural NH (2002) Chloroform adsorption on soil. Chem Eng J 47: 110-1115.

3. Gharbani $P$, Mehrizad A, Ataie S, Mosenharzandi A, Tabatabaei SM, et al. (2011) Adsorption of chloroform from aqueous solution by nano $-\mathrm{TiO}_{2}$. Int J Nano Dimens 1: 287-296.

4. Hamdaouia O, Naffrechoux E (2007) Modeling of adsorption isotherms of phenol and chlorophenols onto granular activated carbon. Part I. Two-parameter models and equations allowing determination of thermodynamic parameters. J Hazard Mater 147: 381-394.

5. Insa S, Salvado V, Antico E (2006) Assays on the simultaneous determination and elimination of chloroanisoles and chlorophenols from contaminated cork samples. J Chromatogr A 1122: 215-221.

6. Kadirova ZC, Okada K, Katsumata K, Isobe T, Matsushita N, et al. (2013) Adsorption and photodegradation of methylene blue by iron oxide impregnated on granular activated carbons in an oxalate solution. J Appl Surf Sci 284: 72-79.

7. Krishnaiah D, Sarbatly R, Anisuzzaman SM, Bono A (2013) Adsorption of 2,4,6- Trichlorophenol (TCP) onto activated carbon. J King Saud University 25: 251-255.

8. Liu X, Li X, Yang Q, Yue X, Shern T, et al. (2012) Landfill leachate pretreatment by coagulation-flocculation process using ironbased coagulants: Optimization by response surface methodology. Chem Eng J 200: 39-51.

9. Michal ski $R$ (2006) Instrumental methods in metal ions speciation: Chromatography, Capillary Electrophoresis and Electrochemistry. Crit Rev Anal Chem 36: 107-127.

10. Ali I, Aboul-Enein H, Gupta V (2009) Nano Chromatography and Capillary Electrophoresis: Pharmaceutical and Environmental Analyses. Wiley \& Sons, Hoboken, USA.

11. Srinivasan A, Chowdhury P, Viraraghavan T (2008) Air Stripping in Industrial Wastewater Treatment. Encyclopedia of Life Support Systems (EOLSS).

12. Robinson T, Mcmultan G, Marchant R, Nigam P (2001) Remediation of dyes in textile effluent: a critical review on current treatment technologies with a proposed alternative. Bio Resource Technology 77: 247-255.
13. Ali I (2012) New Generation Adsorbents for Water Treatment. ACS publication 112: 5073-5091.

14. Ali I (2014) Water Treatment by Adsorption Columns: Evaluation at Ground Level. Separation and purification reviews 43: 175-205.

15. Ali I, Gupta V (2006) Advances in water treatment by adsorption technology. Nature Protocols 1: 2661-2667.

16. Ali I, Aboul Enein $\mathrm{H}$ (2002) Speciation of arsenic and chromium metal ions by reversed phase high performance liquid chromatography. Chemosphere 48: 275-278.

17. Ali I, Gupta V, Khan T, Asim M (2012) Removal of Arsenate from Aqueous Solution by Electro-Coagulation Method Using Al-Fe Electrodes. Int J Electrochem Sci 7: 1898-1907.

18. Meher A, Das S, Rayalu S, Bansiwal A (2016) Enhanced arsenic removal from drinking water by iron-enriched alumino silicate adsorbent prepared from fly ash. Desal wat treat 57: 44 .

19. Ali I, Khan T, Asim M (2012) Removal of arsenate from groundwater by electrocoagulation method. Environ Sci Pollut Res 19: 1668-1676.

20. Ali I, AL-Othman Z, Alwarthan A (2016) Molecular uptake of congo red dye from water on iron composite nano particles. J Mol Liq 224: 171-176.

21. Ali I, AL-Othman Z, Alwarthan Sanagi M (2015) Green Synthesis of Iron Nano-Impregnated Adsorbent for Fast Removal of Fluoride from Water. J Mol Liq 211: 457-465.

22. Alharbi O, Basheer A, Khahab R, Ali I (2018) Health and environmental effects of persistent organic pollutants. J Mol Liq 263: 442-453.

23. Ali I, Alharbi O, AL-Othman Z, Alwarthan A (2018) Facile and ecofriendly synthesis of functionalized iron nanoparticles for cyanazine removal in water. Colloids Surf B Biointerfaces 171: 606-613.

24. Kirsanov MP, Shishkin VV (2016) Evaluation and improving the efficiency of the use of activated carbon for the extraction of organic chlorine compound in water technology. J Food Raw Mater 4: 148-153.

25. Li Sh, Ding L, Zhou P (2011) Adsorption application for removal of hazardous Chloroform from aqueous solution by Nano composites Recto rite/Chitosan adsorbent. J Water Resource Prot 3: 448-455.

26. Ling X, Li J, Zhu W, Zhao Y, Sheen J, et al. (2012) Synthesis of Nano scale zero-valent iron/ordered mesoporous carbon for adsorption and synergistic reduction of nitrobenzene. J Chemosphere 87: 655-660.

27. Ali I, Alharbi O, Alothman Z, Badjah A, Alwarthan A, et al. (2018) Artificial neural network modeling of amid black dye sorption on iron composite Nano material: Kinetics and thermodynamics studies. J Mol Liq 250: 1-5.

28. Burakova E, Dyachkova T, Rudov A, Tugolukov E, Glaluin E, et al. (2018) Novel and economic method of carbon nanotubes synthesis on a nickel magnesium oxide catalyst using microwave radiation. J Mol Liq 253: 340-346.

29. Ali I, Khan T, Asim M (2011) Removal of Arsenic from Water by Electrocoagulation and Electro dialysis Techniques. Separation and purification reviews 40: 1 .

30. Ali I, Alothman Z, Alwarthan A (2017) Supra molecular mechanism of the removal of $17-\beta$ - estradiol endocrine 
disturbing pollutant from water on functionalized iron Nano particles. J Mol Liq 241: 123-129.

31. Ali I, Alothman Z, Alwarthan A (2017) Uptake of propranolol on ionic liquid iron Nano composite adsorbent: Kinetic, thermodynamics and mechanism of adsorption. J Mol Liq 236: 205-213.

32. Ali I, Alothman Z, Alwarthan A (2016) Molecular uptake of congo red dye from water on iron composite nano particles. J Mol Liq 224: 171-176.

33. Dehghan M, Sanaei D, Ali I, Bhatn agar A (2016) Removal of chromium(VI) from aqueous solution using treated waste newspaper as a low-cost adsorbent: Kinetic modeling and isotherm studies. J Mol Liq 215: 671-679.

34. Ali I, Jain Ch (2004) Advances in arsenic speciation techniques. Int J Anal Chem 8: 12.

35. Suhail M, Ali I (2017) Advanced spiral periodic classification of the Elements. Poster.

36. Ali I, Alothman Z, Alwarthan A (2016) Sorption, kinetics and thermodynamics studies of atrazine herbicide removal from water using iron Nano-composite material. Inter J Environ Sci Technol 13: 733-742.

37. Ali I, Alothman Z, Alwarthan A (2016) Removal of secbumeton herbicide from water on composite Nano adsorbent. J Desalin Water Treat 57: 10409-10421.

38. Ali I, Alothman Z, Alwarthan A (2016) Uptake of pantoprazole drug residue from water using novel synthesized composite iron nano adsorbent. J Mol Liq 218: 465- 472.

39. Ali I, Alothman Z, Alwarthan A (2016) Green synthesis of functionalized iron Nano particles and molecular liquid phase adsorption of ametryn from water. J Mol Liq 221: 1168-1174.

40. Ali I, Alothman Z, Alwarthan A (2016) Synthesis of composite iron nano adsorbent and removal of ibuprofen drug residue from water. J Mol Liq 219: 858-864.
41. Ali I, Asim M, Khan T (2013) Arsenite removal from water by electro-coagulation on zinc-zinc and copper-copper electrodes. Inter J Environ Sci Technol 10: 377-384.

42. Noubactep C, Caren R, Care S (2012) Nano scale metallic iron for environmental remediation: prospects and limitations. J Water Air Soil Pollut 223: 1363-1382.

43. Park J, Kim H, Han Y (2012) Formation of mesoporous materials from silica dissolved in various $\mathrm{NaOH}$ concentrations: Effect of pH and ionic strength. J Nano Mater 2012: 1-10.

44. Petala E, Karakassides MA, Dimos K, Zboril R, Douvalis A, et al. (2013) Nano scale zero-valent iron supported on mesoporous silica: Characterization and reactivity for $\mathrm{Cr}(\mathrm{VI})$ removal from aqueous solution. J Hazard Mater 216: 295-306.

45. Sun X, Wang L, Yan Y, Li J, Han W (2014) SAB-15-incorporated nanoscale zero- valent iron particles for chromium(VI) removal from groundwater: Mechanism, effect of $\mathrm{pH}$, humic acid and sustained reactivity. J Hazard Mater 12: 26-33.

46. Tahir NM, Ariffin MM, Khoon TS, Hui TJ, Suratman S (2008) Adsorption of chloroform -ethyl and metasulfuron-methyl on selected Selangor agricultural soils. T Mal J Anal Sci 12: 341-347.

47. Tay T, Ceylan B, Erdem M, Karagoz S (2012) Adsorption of methylene blue from aqueous solution on activated carbon produced from soybean oil cake by $\mathrm{KOH}$ activation. J Bioresour 7: 3175-3187.

48. Tan IW, Hameed BH, Ahmad L (2008) Adsorption of basic dye on high-surface-area activated carbon prepared from coconut husk: Equilibrium, kinetic and thermodynamic studies. J Hazard Mater 154: 337-346.

49. Tebeje $Z$ (2011) GAC Adsorption processes for chloroform removal from drinking water. Ta J N Appl Sci 21: 352-358.

50. Wang P, Cao M, Qian J, Wang Ch, Ao Y, et al. (2014) Kinetics and thermodynamics of adsorption of methylene blue by a magnetic graphene-carbon nanotube composite. J Appl Surf Sci 290: 116-124. 